\title{
Anticardiolipin Antibodies and Lupus Anticoagulants among Women Undergoing In Vitro Fertilization in Jamaica
}

\author{
V DaCosta, L Chin, S Wynter, J Harriott, L Christie, S Frederick-Johnston, J Frederick, C McKenzie, D Everett, \\ R Foster, Y Walters, A Pottinger
}

\begin{abstract}
Objective: The aims of this study were to evaluate the effect of anticardiolipin antibody (aCL) and lupus anticoagulant (LA) on the outcome of the in vitro ferlitization (IVF) cycles and to determine the prevalence of these antibodies in infertile women seeking IVF in Jamaica.

Methods: A retrospective cohort study was performed to determine if screening patients for aCL and LA had any significant impact on the outcome of the IVF process. Each patient's hospital record, between March 2000 and March 2010, was collected and the relevant data extracted.

Results: The prevalence of aCL in this cohort of Jamaican women was moderate/high positive 3.88\%, low positive $0.68 \%$ and those with negative aCL results $95.4 \%$. The prevalence of women who were $L A$ positive was $4.1 \%$ and $0.9 \%$ of the women were positive for both $L A$ and $a C L$. Of the patients who were $L A$ and/or aCL positive, eight out of 30 patients (26.7\%) had a positive pregnancy test in comparison to 61 out of 181 patients (33.7\%) who were LA and/or aCL negative ( $\mathrm{p}=0.5787)$.

Conclusion: The prevalence of positive aCL and/or LA in infertile women seeking IVF in Jamaica is $7.76 \%$. The presence of these antibodies did not affect the pregnancy rate of these women nor did it demonstrate an increased risk for IVF cycle cancellation or ovarian hyperstimulation syndrome. Screening women undergoing IVF for these antibodies is not justified.
\end{abstract}

Keywords: Anticardiolipin antibodies, IVF, Jamaica, lupus anticoagulants

\section{Anticuerpos Anticardiolipinas y Anticoagulantes Lúpicos entre Mujeres a las que se les Realiza FIV en Jamaica}

V DaCosta, L Chin, S Wynter, J Harriott, L Christie, S Frederick-Johnston, J Frederick, C McKenzie, D Everett, R Foster, Y Walters, A Pottinger

\begin{abstract}
RESUMEN
Objetivo: Los objetivos de este estudio fueron evaluar el efecto del anticuerpo anticardiolipina (aCL) y el anticoagulante lúpico (LA) sobre el resultado de los ciclos de la fertilización en vitro (FIV), así como determinar la prevalencia de estos anticuerpos en mujeres estériles que buscan tratamiento de FIV en Jamaica.

Métodos: Se realizó un estudio de cohorte para determinar si el tamizaje de pacientes para detectar el anticuerpo anticardiolipina y el anticoagulante lúpico tenía un impacto significativo en el resultado del proceso de FIV. Se obtuvieron las historias clínicas hospitalarias de cada una de las pacientes, entre marzo de 2000 y marzo de 2010, y se extrajeron los datos pertinentes.

Resultados: La prevalencia de aCL en esta cohorte de mujeres jamaicanas fue $3.88 \%$ moderadalalta positiva, $0.68 \%$ positiva baja, y aquellas con resultados negativos de aCL, 95.4\%. La prevalencia de mujeres con resultados de anticoagulante lúpico positivos fue $4.1 \%$, y $0.9 \%$ de las mujeres resultaron positivas con respecto tanto al $L A$ como al aCL. De las pacientes que fueron positivas al LA y/o al aCL, ocho de cada 30 pacientes (26.7\%) tuvieron una prueba de embarazo positiva, en comparación con 61 de cada 181 pacientes (33.7\%) negativas al LA y/o al aCL $(\mathrm{p}=0.5787)$.
\end{abstract}

From: Hugh Wynter Fertility Management Unit, The University of the West Indies, Kingston 7, Jamaica, West Indies.
Correspondence: Dr V DaCosta, Hugh Wynter Fertility Management Unit, The University of the West Indies, Kingston 7, Jamaica, West Indies. E-mail: ved111@hotmail.com 
Conclusión: La prevalencia de resultados positivos en relación con anticuerpos anticardiolipinas y/o anticoagulantes lúpicos en mujeres estériles que buscan FIV en Jamaica es $7.76 \%$. La presencia de estos anticuerpos no afectó la tasa de embarazo de estas mujeres, ni mostró un aumento de riesgo de la cancelación del ciclo FIV, o riesgo de síndrome de hiperestimulación ovárica. El tamizaje en busca de estos anticuerpos en mujeres que buscan tratamiento de FIV, no está justificado.

Palabras claves: Anticuerpos anticardiolipinas, FIV, Jamaica, anticoagulantes lúpicos

West Indian Med J 2012; 61 (8): 790

\section{INTRODUCTION}

Antiphospholipid syndrome (APS) or the presence of antiphospholipid antibodies (aPLs) and lupus anticoagulant (LA) usually present as pregnancy loss and/or thrombosis. However, aPLs have also been reported to affect implantation, placentation, and early embryonic development. The binding of aPL to beta-2 glycoprotein-1 (GPl) may lead to breakdown of the phospholipid adhesion molecules between different elements of trophoblast (1). As aPLs affect placental growth and function, aPLs may prevent implantation presenting as infertility. The lupus anticoagulant and anticardiolipin antibodies have been implicated in the prothrombotic effects of APS (1). The presence of aPLS among infertile women is likely to be a part of a generalized autoimmune disturbance associated with infertility (2).

If the presence of aPLs or LA alone, without the APS or systemic lupus erythematosus (SLE), does not affect the outcome of assisted reproductive technology (ART), then screening or therapy is not justified.

The Hugh Wynter Fertility Management Unit (HWFMU) at the University of the West Indies is faced with a "high" demand for assisted reproductive techniques from females of all ages and social classes. It is therefore very important that we keep the cost of this procedure as low as possible. One of the ways that we can decrease the patient's expense is to avoid doing unnecessary costly investigations.

The clinical relevance of the aPLs in women undergoing in vitro fertilization/embryo transfer (IVF/ET) and the role of IVF treatment in affecting antiphospholipid levels are controversial.

Wharfe et al (3) showed that the incidence of anticardiolipin antibody (aCL) in a cohort of Jamaican women with miscarriages was moderate/high positive in $15.2 \%$, low positive in $23.1 \%$ and negative in $61.6 \%$. The paper concluded that "the prevalence of positive immunoglobulin-G aCL tests was high in this cohort of patients with spontaneous abortion. However, intervention is not necessary in many of these patients who have only a positive aCL test but none of the clinical conditions of the antiphospholipid syndrome". Other studies have supported this conclusion (4-6).

In a recently published Jamaican study by Roye-Green et al (7), blood samples from 50 women who had had recurrent spontaneous abortions and 135 healthy multiparous women were investigated for aCL and anti- $\beta-2$ GP1 dependent aCL antibodies by enzyme-linked immunosorbent assays (ELISA). Lupus anticoagulant activity was measured by activated partial thromboplastin time, anti-nuclear antibodies, rheumatoid factors and thyroid antibodies using standard techniques.

There was no significant difference in the prevalence of autoantibodies in habitual aborters and control subjects (60\% and 44\%, respectively). Habitual aborters differed from controls only in the prevalence of positive aCL tests $(15 / 50,30 \%$ vs $15 / 135,11 \%, p=0.01)$, medium/high concentrations of aCL $(9 / 50,18 \%$ vs $9 / 135,7 \%, p=0.05)$; aCL of the $\operatorname{IgM}$ isotype $(8 / 50,16 \%$ vs $7 / 135,5 \%, p=0.05)$ and anti- $\beta-2$ GP1 antibodies (7/50, 14\% vs 3/135, $2 \%, p=0.05)$. They recommended aCL screening in habitual aborters and the performance of the anti- $\beta-2$ GP1 antibody tests to identify those most at risk.

Some reports have suggested a relationship between aPLs and infertility and poor ART outcome $(1,8)$. However, recent studies have not detected a higher prevalence of these autoantibodies in infertile women, or a correlation with the type of female infertility diagnosis (9). Another group failed to observe a higher prevalence of LA or aCL in women with unexplained infertility than in a control group of fertile egg donors (10). In addition, the presence of aPLs does not seem to affect ART outcome (11), and therefore therapy is not justified (9). The presence of aPLs among infertile women is likely to be a part of a generalized autoimmune disturbance that may be associated with infertility (2). Hence, routine screening is not warranted in the infertile population and therapeutic interventions are not to be advised, except in the case of women with other features of APS, for example, recurrent miscarriage or pregnancy complications $(9,12)$.

The aims of this study are to evaluate the effect of anticardiolipin antibody and lupus anticoagulant on the outcome of the IVF cycles at the HWFMU and to determine the prevalence of these antibodies in infertile women seeking IVF at the HWFMU.

\section{SUBJECTS AND METHODS}

Between March 2000 and March 2010, all patients attending the HWFMU for IVF with moderate/high positive aCL, those with low positive aCL, and those with positive LA antibody 
results were identified, along with randomly assigned controls with similar demography. All patients undergoing IVF gave their consent for the above investigations to be performed.

A retrospective cohort study was performed to determine if screening patients for the aCL and LA had any significant impact on the outcome of the IVF process. Each patient's hospital record was collected and the relevant data extracted (Appendix).

Inclusion criteria for cases included all patients undergoing IVF with a positive aCL and/or positive LA result. Inclusion criteria for controls included all patients undergoing IVF with a negative $\mathrm{aCL}$ and negative LA result.

Exclusion criteria for cases included patients with a history of having APS or SLE and patients who were taking steroids or those who discontinued steroids within three months of starting IVF. Exclusion criteria for controls were patients with a history of having APS, SLE, or a positive $\mathrm{aCL}$, or positive LA result.

The statistical package, SPSS version 17, was utilized for data analysis and independent sample $t$-tests and Chisquare statistics were used to compare differences in the outcomes in the two groups and determine statistical significance.

\section{RESULTS}

Between March 2000 and March 2010, 438 patients attended the HWFMU for IVF and met the criteria for inclusion in the study. Thirty-four of these patients were positive for LA and/or aCL. Thus, the prevalence of these antibodies in infertile women seeking IVF at the HWFMU was calculated to be $7.76 \%$.

The prevalence of the aCL in this cohort of Jamaican women was moderate/high positive in $3.88 \%$, low positive in $0.68 \%$ and negative aCL results in $95.4 \%$. The prevalence of women who were LA positive was $4.1 \%$ and $0.9 \%$ of the women were positive for both LA and aCL.

The demographic data of age, height, weight and body mass index (BMI) were found to be similar between the two groups with no statistical differences (Table 1).

The most common cause of infertility among the women presenting for IVF was due to a male factor (45\%). This was followed by tubal disease $(31.5 \%)$, endometriosis $(10.5 \%)$, uterine factors $(4.6 \%)$, unexplained factors $(4.6 \%)$ and ovarian factors (3.8\%) [Figure].

The means of the following variables for those patients who were aCL and/or LA negative and positive were analysed: duration of infertility, total number of antral follicles (2-10 $\mathrm{mm}$ in size), day three luteinizing hormone (LH), follicle stimulating hormone (FSH) and oestradiol levels, number of follicles measuring greater than $14 \mathrm{~mm}$ at the time of stimulation with human chorionic gonadotrophin (hCG),
Table 1: Demographic characteristics of the patients

\begin{tabular}{lcccccccc}
\hline & \multicolumn{3}{c}{ Lupus and/or anticardiolipin status } & $p$-value \\
& \multicolumn{2}{c}{ Negative } & \multicolumn{3}{c}{ Positive } & \\
& N & Mean & SD & N & Mean & SD & \\
& 204.0 & 35.2 & 4.8 & 34.0 & 35.6 & 5.1 & 0.6 \\
\hline Age (years) & 202.0 & 71.8 & 14.1 & 34.0 & 74.4 & 15.0 & 0.2 \\
Weight (kg) & 202.0 & 1.6 & 0.1 & 34.0 & 1.7 & 0.1 & 0.4 \\
$\begin{array}{l}\text { Height (m) } \\
\begin{array}{l}\text { Body mass index } \\
\left(\mathrm{kg} / \mathrm{m}^{2}\right)\end{array}\end{array}$ & 200.0 & 26.5 & 4.9 & 34.0 & 27.3 & 5.4 & 0.6 \\
\hline
\end{tabular}

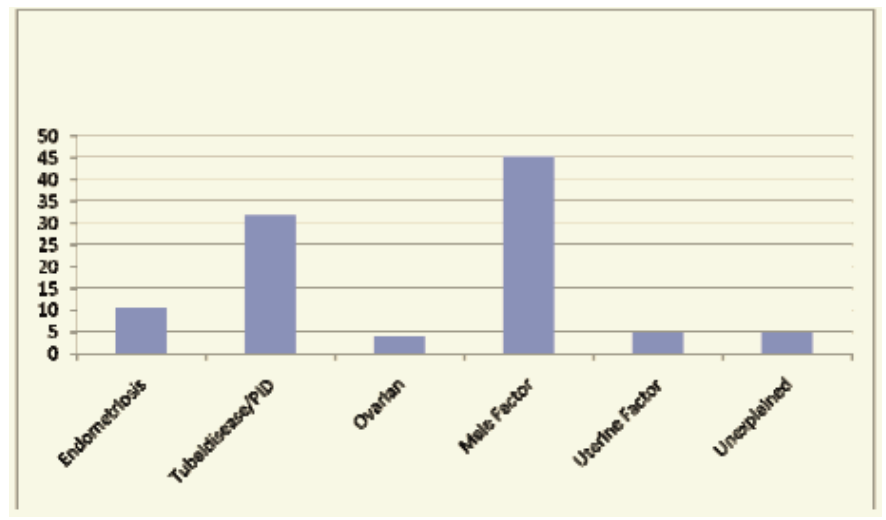

Figure: Causes of infertility among women presenting for in vitro fertilization at the Hugh Wynter Fertility Management Unit.

number of oocytes retrieved, number of oocytes fertilized, total number of embryos obtained, and the number of embryos transferred. There was no statistical difference between the two groups [Table 2]. Of the patients who were LA and/or aCL positive, four out of 34 patients $(11.8 \%)$ had cancellation of their IVF cycle in comparison to 26 out of 205 patients $(12.7 \%)$ who were LA and/or aCL negative [Table 3]. This difference was found to be statistically significant using Chi-square analysis $(p=0.02)$.

With regards to a positive pregnancy test, of the patients who were LA and/or aCL positive, eight out 30 patients $(26.7 \%)$ had a positive pregnancy test in comparison to 61 out of 181 patients $(33.7 \%)$ who were LA and/or aCL negative [Table 4]. This difference was not statistically significant using Chi-square analysis $(p=0.5787)$.

With regards to the occurrence of ovarian hyperstimulation syndrome (OHSS), of the patients who were LA and/or aCL positive, two out 31 patients $(6.5 \%)$ developed OHSS in comparison to 12 out of 174 patients $(6.9 \%)$ who were LA and/or aCL negative [Table 5]. This difference was statistically significant using Chi-square analysis $(p=$ $0.0082)$. 
Table 2: Data obtained for lupus anticoagulant (LA) and/or anticardiolipin antibody (aCL) positive patients versus LA and/or aCL negative patients

\begin{tabular}{|c|c|c|c|c|c|c|c|c|c|}
\hline \multirow[t]{3}{*}{ Variable } & \multicolumn{8}{|c|}{ Lupus anticoagulant and anticardiolipin status } & \multirow[t]{3}{*}{$p$-value } \\
\hline & \multirow[b]{2}{*}{$\mathbf{N}$} & \multicolumn{3}{|c|}{ Negative } & \multicolumn{4}{|c|}{ Positive } & \\
\hline & & Mean & $\min$ & Max & $\mathbf{N}$ & Mean & $\min$ & $\max$ & \\
\hline $\begin{array}{l}\text { Duration of infertility } \\
\text { (years) }\end{array}$ & 201 & 4 & 1 & 20 & 34 & 3 & 1 & 15 & 0.3 \\
\hline LH (IU/L) & 203 & 4 & 1 & 25 & 34 & 4 & 1 & 14 & 0.7 \\
\hline FSH (IU/L) & 204 & 6 & 1 & 17 & 34 & 7 & 1 & 24 & 0.7 \\
\hline Oestradiol (pmol/ml) & 198 & 51 & 0 & 386 & 33 & 54 & 1 & 170 & 0.5 \\
\hline Number of antral follicles & 201 & 4 & 0 & 45 & 34 & 3 & 0 & 16 & 0.7 \\
\hline $\begin{array}{l}\text { Number of follicles }>14 \mathrm{~mm} \\
\text { at the time of stimulation }\end{array}$ & 201 & 8 & 0 & 32 & 34 & 7 & 1 & 20 & 0.2 \\
\hline Oocytes retrieved & 192 & 9 & 0 & 42 & 32 & 9 & 2 & 23 & 0.7 \\
\hline Oocytes fertilized & 188 & 5 & 0 & 19 & 31 & 4 & 0 & 13 & 0.8 \\
\hline Total embryos obtained & 186 & 4 & 0 & 16 & 30 & 4 & 1 & 13 & 0.3 \\
\hline Total embyros transferred & 187 & 2 & 0 & 6 & 30 & 3 & 1 & 5 & 0.3 \\
\hline $\begin{array}{l}\text { Total number of transfer } \\
\text { procedures }\end{array}$ & 187 & 1 & 0 & 2 & 30 & 1 & 0 & 2 & 0.8 \\
\hline
\end{tabular}

$\mathrm{LH}=$ luteinizing hormone; $\mathrm{FSH}=$ follicle stimulating hormone

Table 3: Cancellation of in vitro fertilization (IVF) cycles with respect to lupus anticoagulant and anticardiolipin status

\begin{tabular}{lccr}
\hline Cycle cancelled & \multicolumn{2}{c}{$\begin{array}{c}\text { Lupus anticoagulant and } \\
\text { anticardiolipin status }\end{array}$} & Total \\
& Negative & Positive & \\
\hline No & 179 & 30 & 209 \\
Yes & 26 & 4 & 30 \\
Total & 205 & 34 & 239 \\
\hline
\end{tabular}

Chi-square $p$-value $=0.02$

Table 4: Positive pregnancy test results with respect to lupus anticoagulant and anticardiolipin status

\begin{tabular}{lccc}
\hline $\begin{array}{l}\text { Positive pregnancy } \\
\text { Test }\end{array}$ & \multicolumn{2}{c}{$\begin{array}{c}\text { Lupus anticoagulant and } \\
\text { anticardiolipin status }\end{array}$} & Total \\
& Negative & Positive & \\
\hline No & 120 & 22 & 142 \\
Yes & 61 & 8 & 69 \\
Total & 181 & 30 & 211 \\
\hline
\end{tabular}

Chi-square $p$-value $=0.5787$

\section{DISCUSSION}

The analysis of this study revealed that the prevalence of LA and aCLs $(7.76 \%)$ was low in this cohort of women. There were no significant differences between the two groups in clinical characteristics such as age, infertility duration, and
Table 5: Occurrence of ovarian hyperstimulation syndrome (OHSS) in patients with respect to lupus anticoagulant and anticardiolipin status

\begin{tabular}{llll}
\hline OHSS & \multicolumn{2}{l}{$\begin{array}{l}\text { Lupus anticoagulant and } \\
\text { anticardiolipin status }\end{array}$} & Total \\
& Negative & \multicolumn{1}{c}{ Positive } & \\
\hline No & $162(93.1 \%)$ & $29(93.5 \%)$ & $191(93.2 \%)$ \\
Yes & $12(6.9 \%)$ & $2(6.5 \%)$ & $14(6.8 \%)$ \\
Total & 174 & 31 & 205 \\
\hline
\end{tabular}

Chi-square $p$-value $=0.0082$

response to controlled ovarian hyperstimulation. The prevalence in this study is much lower than that reported by the Practice Committee of the American Society for Reproductive Medicine (12), and Chilcott et al (13). This prevalence is also lower than those reported by Wharfe et al (3) and Roye-Green et al (7), two other Jamaican studies. The lower prevalence of LA and aCLs in this study may be related to the high prevalence of male infertility (Figure) in the study population.

This study also showed that pregnancy rate, live birth rate, gestational age at delivery and birthweight were not affected by the presence of aPL and/or LA in patients undergoing IVF. This is in agreement with Bellver et al (10) and a meta-analysis by Horstein et al (11).

The prevalence of the aCL in this cohort of Jamaican women was moderate/high positive $3.88 \%$, low positive $0.68 \%$ and negative aCL results $95.4 \%$. These figures are 
much lower than those reported in previous studies on cohorts of Jamaican women with histories of habitual abortion $(3,7)$. Previous evaluation of aCL levels and the effect of IVF treatment on aCL in women undergoing their first IVF/ET cycle indicated that IVF treatment increased IgGaCL levels in patients with endometriosis and tubal factor infertility, but their presence seemed to have no clinical relevance or effect on the IVF cycle outcome (14).

This study demonstrated no difference in the percentage of patients who achieved a biochemical pregnancy among the women who tested negative and those who tested positive. This is in contrast to a previous study which analysed the influence of maternal immunological factors on clinical pregnancy outcome in an IVF-ET programme (15). One hundred and fifty IVF-ET treatment cycles were studied. A lower pregnancy rate $(9.5 \%)$ was found in the aPL-positive group, compared with $26.3 \%$ in seronegative women ( $p<$ 0.05 ). They concluded that serum immunological factors may play a part in clinical pregnancy outcome in IVF-ET. However, more recent studies $(2,13)$ have refuted this finding and report similar findings with the present study.

A prospective study published in 2007 by Sanmarco et al (15) assessed the prevalence of aPLs in women who had undergone IVF and the relationship between aPLs and IVF outcome. All were evaluated for the presence of LA, antibodies (IgG, IgA, IgM) to cardiolipin (aCL), anti- $\beta-2$ GP1 and phosphatidylethanolamine (aPE). Out of 101 infertile women, 40 were persistently positive for aPL, showing a prevalence significantly higher than in controls $(39.6 \%$ vs $5 \%, p<0.0001)$. Among aPL, aPE was found with a significantly higher prevalence compared with LA, aCL, and aB2GPI (67.5\% vs $0 \%, 15 \%$, and $40 \%$, respectively). The study by Sanmarco et al (15) demonstrated aPE as the most prevalent aPL in infertile women and the results did not support an association between aPL and IVF outcome.

The present study also demonstrated that there was no increased risk for cycle cancellation or the development of the OHSS among women who were LA or aCL antibody positive. These findings support the recommendation to eliminate these costly investigations from the evaluation of the infertile couple presenting for IVF. Limitations of this study stemmed from noted deficiencies in documentation which would have allowed for further analysis of pregnancy outcomes. The majority of the patients returned to their referring obstetrician-gynaecologist after their positive pregnancy test, and were lost to follow-up, thus precluding analysis of the live birth rate.

\section{CONCLUSION}

Approximately $8 \%$ of the infertile women seeking IVF at the HWFMU over the ten-year period studied were aCL and/or
LA positive. The presence of these antibodies did not affect the pregnancy rate of these women nor did it demonstrate an increased risk for an IVF cycle cancellation or OHSS. Screening women undergoing IVF for these anti-bodies is not justified. Thus, there is the potential benefit from a health economics viewpoint in eliminating these un-necessary investigations and their associated cost.

\section{REFERENCES}

1. Carp HJ, Shoenfeld Y. Anti-phospholipid antibodies and infertility. Clin Rev Allergy Immunol 2007; 32: 159-61.

2. J Bellver, Pellicer A. Ovarian stimulation for ovulation induction and in vitro fertilization in patients with systemic lupus erythematosus and antiphospholipid syndrome. Fertil Steril 2009; 2: 1803-10.

3. Wharfe G, Fletcher H, Smikle M, Frederick J, Reid M. The prevalence of positive anticardiolipin antibody in Jamaican women with spontaneous abortion and the correlation with past clinical history $\mathrm{J}$. Obstet Gynaecol 2004; 24: 452-4.

4. Lee SR, Park EJ, Kim SH, Chae H, Kim CH, Kang BM. Influence of antiphospholipid antibodies on pregnancy outcome in women undergoing in vitro fertilization and embryo transfer. Am J Reprod Immunol 2007; 57: 34-9.

5. Fábregues F, Tàssies D, Reverter JC, Carmona F, Ordinas A, Balasch J. Prevalence of thrombophilia in women with severe ovarian hyperstimulation syndrome and cost-effectiveness of screening. Fertil Steril 2004; 81: 989-95.

6. Backos M, Rai R, Regan L. Antiphospholipid antibodies and infertility. Hum Fertil (Camb) 2002; 5: 30-4.

7. Roye-Green K, Frederick J, Wharfe G, Choo-Kang E, DaCosta V, Fletcher $\mathrm{H}$ et al. Antiphospholipid and other autoantibodies in a cohort of habitual aborters and healthy multiparous women in Jamaica. Hum Antibodies 2011; 20: 1-5.

8. Stern C, Chamley L, Hale L, Kloss M, Speirs A, Baker HW. Antibodies to beta2 glycoprotein I are associated with in vitro fertilization implantation failure as well as recurrent miscarriage: results of a prevalence study. Fertil Steril 1998; 70: 938-44.

9. Cervera R, Balasch J. Bidirectional effects on autoimmunity and reproduction. Hum Reprod Update 2008; 14: 359-66.

10. Bellver J, Soares SR, Alvarez J, Muñoz E, Ramírez A, Rubio C et al. The role of thrombophilia and thyroid autoimmunity in unexplained infertility, implantation failure and recurrent spontaneous abortion. Hum Reprod 2008; 23: 278-84.

11. Horstein MD, Davis OK, Massey JB, Paulson RJ, Collins JA. Antiphospholipid antibodies and in vitro fertilization success: a metaanalysis. Fertil Steril 2000; 73: 330-3.

12. The Practice Committee of the American Society for Reproductive Medicine. Antiphospholipid antibodies do not affect IVF success. Fertil Steril 2006; 86: S224-S5.

13. Chilcott IT, Margara R, Cohen H, Rai R, Skull J, Pickering W et al. Pregnancy outcome is not affected by antiphospholipid antibody status in women referred for in vitro fertilization. Fertil Steril 2000; 73: 526-30.

14. Hammond ME, Hayes DF, Dowsett M, Allred DC, Hagerty KL, Badve $\mathrm{S}$ et al. American Society of Clinical Oncology/College of American Pathologists guideline recommendations for immunohistochemical testing of estrogen and progesterone receptors in breast cancer. Arch Pathol Lab Med 2010; 134: 907-22.

15. Sanmarco M, Bardin N, Camoin L, Beziane A, Dignat-George F, Gamerre $M$ et al. Antigenic profile, prevalence, and clinical significance of antiphospholipid antibodies in women referred for in vitro fertilization. Ann N Y Acad Sci 2007; 1108: 457-65. 


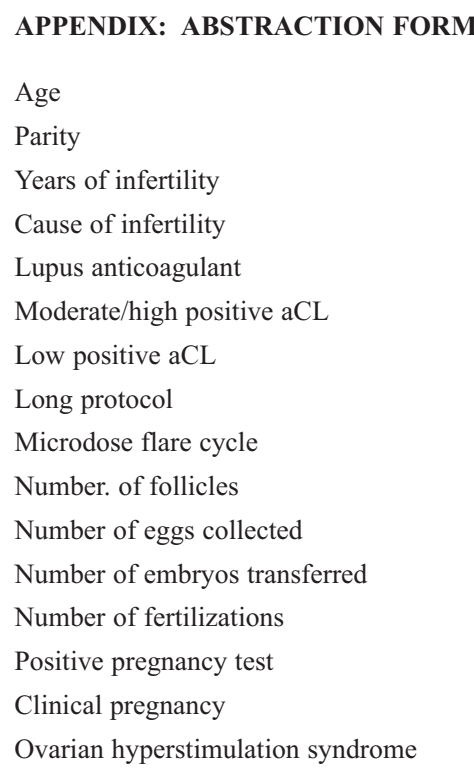

The Fertility Management Lnit, Department of Obstetrics and Gynaecology and Child Health, The lniversity of the West Indies, Kingston, Jamaica.

- Intra-ilterine Insemination (ILiI)

- Ir Vitro lertilization and I:mbryo Transfer

- Cryopreservation and Fromen Embryo Transfer

- Semen Analysis

- Testicular Sperm Aspiration (TESA)

Telephone: (876) 970-2388

Fax : (876)927-0100

E-mail: joseph. Irederick (auwimona.edu.jm 